\title{
양파 $\mathrm{F}_{1}$ 종자생산을 위한 조생계 웅성불임계통 '원예 30005'
}

\author{
김철우 $^{1^{*}} \cdot$ 이을 태 ${ }^{2} \cdot$ 최인후 $^{2} \cdot$ 장영석 $^{2} \cdot$ 배상경 $^{1} \cdot$ 서세정 ${ }^{3}$ \\ ${ }^{1}$ 국립원예특작과학원, ${ }^{2}$ 바이오에너지작물연구소, ${ }^{3}$ 식품의약품안전처
}

\section{Early Maturing Male Sterile Line 'Wonye 30005' for Hybrid Seed Production of Onion (Allium cepa $\mathbf{L}$.)}

\author{
Cheol-Woo Kim ${ }^{1^{*}}$, Eul-Tai Lee ${ }^{2}$, In-Hu Choi ${ }^{2}$, Young-Seok Jang ${ }^{2}$, Sang-kyeong Bae ${ }^{1}$, and Sae-Jung Suh ${ }^{3}$ \\ ${ }^{1}$ Vegetable Research Division, NIHHS, RDA, Jeonju 565-852, Korea, \\ ${ }^{2}$ Bioenergy Crop Research Center, NICS, RDA, Muan 534-833, Korea \\ ${ }^{3}$ Ministry of Food And Drug Safty, 361-951, Korea
}

\begin{abstract}
Male sterile line in onion is essential to the development of hybrid varieties. Onion male sterile line 'Wonye30005' was developed by Bioenergy Crop Research Center, NICS, RDA in South Korea in 2010. Lodging date of 'Wonye30005' is May 15 ${ }^{\text {th }}$ and it belongs to the early maturing type in Korea. We found the male sterile plants in 'Hamasodachi', early maturing open-pollinated variety, and the male-sterile plants were cross-pollinated with male fertile line, 'M330', the population of $F_{1}$ showed $100 \%$ male sterility and the F1 plants were subsequently backcrossed for five generations. 'Wonye 30005 ' was numbered as 'MMS77' in 2009 and the corresponding male parent is called MMSB77. 'Wonye30005' has round bulb shape (Bulb index, 97), cold resistance, and excellent storage quality and average bulb weight is $253 \mathrm{~g}$. Flowering date is May $25^{\text {th }}$ and flower bud size is $84 \mathrm{~mm}$ in full bloom. The number and length of flower stalks per bulb are 4 and $134 \mathrm{~cm}$, respectively. 'Wonye 30005 ' has been filed in Korea Seed and Variety Service in 2010. Overall, 'Wonye30005' is promising male sterile line for early maturing type hybrid seed production and breeding program. (no 4673)
\end{abstract}

Keywords : Onion, Allium cepa, Male sterile line, Wonye30005

\section{서 언}

양파(Allium cepa L.)는 백합과(Liliaceae) Allium 속의 양념채 소다. 국내 양파 재배면적은 2010년 이래 연간 2.0 2.2만 ha에서 $120 ~ 150$ 만 톤이 생산되고 있다. 특히 양파는 고유의 양념채소로 서의 기능뿐만 아니라 셀러드, 양파즙, 음료, 기타 식품첨가물 등 그 용도가 다양해지고 있다. 국내에서 재배되는 양파는 단일형 품종군에 속하며 숙기에 따라서 조생종과 중만생종, 만생종으로 구분된다. 조생종은 월동기간이 온난한 제주도와 남부해안지역 에서 주로 재배되고, 중만생종과 만생종은 남부내륙과 중부지방 에 주산지를 이루고 있다. 양파 $\mathrm{F}_{1}$ 종자생산에 이용되는 웅성불임 은 1925년 Dr. Jones가 'Italian Red'에서 웅성불임을 처음 발견

*Corresponding author (E-mail: cwkim@korea.kr, Tel.: + 82-61450-0193; Fax: + 82-61-453-0085)

(Received on July 30, 2015. Accepted on March 2, 2016.)
하였고 Jones와 Clarke(1943)에 의해 웅성불임의 유전과 $\mathrm{F}_{1}$ 종자 생산방법이 밝혀졌다. 현재까지 알려진 웅성불임 세포질 종류는 CMS-S와 CMS-T이며 CMS-S는 1925년 Dr. Jones가 'Italian Red'에서 발견하였고 1965년에 Berninger는 CMS-S와는 회복 유전양상이 다른 새로운 $\mathrm{CMS}-\mathrm{T}$ 를 발견하여 $\mathrm{F}_{1}$ 종자생산에 이용하고 있다 (Berninger 1965, Schweisguth 1973, Havey 2000). 국내에서는 CMS-S와CMS-T를 모두 $\mathrm{F}_{1}$ 종자생산에 사용 하고 있으며 국내에서 개발된 $\mathrm{F}_{1}$ 품종의 mitotype를 분석한 결과 CMS-T가 $48 \%, \mathrm{CMS}-\mathrm{S}$ 가 $15 \%$ 였다(Kim et al. 2009a). 양파는 2 년 1 세대 타식성 작물로 육종연한이 길고 자식약세가 심하여 선발과 고정에 어려움이 많은 작물이다. 양파 웅성불임계 통(A-line)과 웅성불임유지계통(maintainer, B-line) 선발은 임 의적인 교배를 통해 얻은 $\mathrm{F}_{1}$ 의 임성확인을 거치는 관행 육종방법 을 이용할 경우 짧게는 4 년, 길게는 8 년 이상이 소요되어 $\mathrm{F}_{1}$ 품종개발에 가장 큰 장애요인이 되고 있다. 그러나 최근에는 


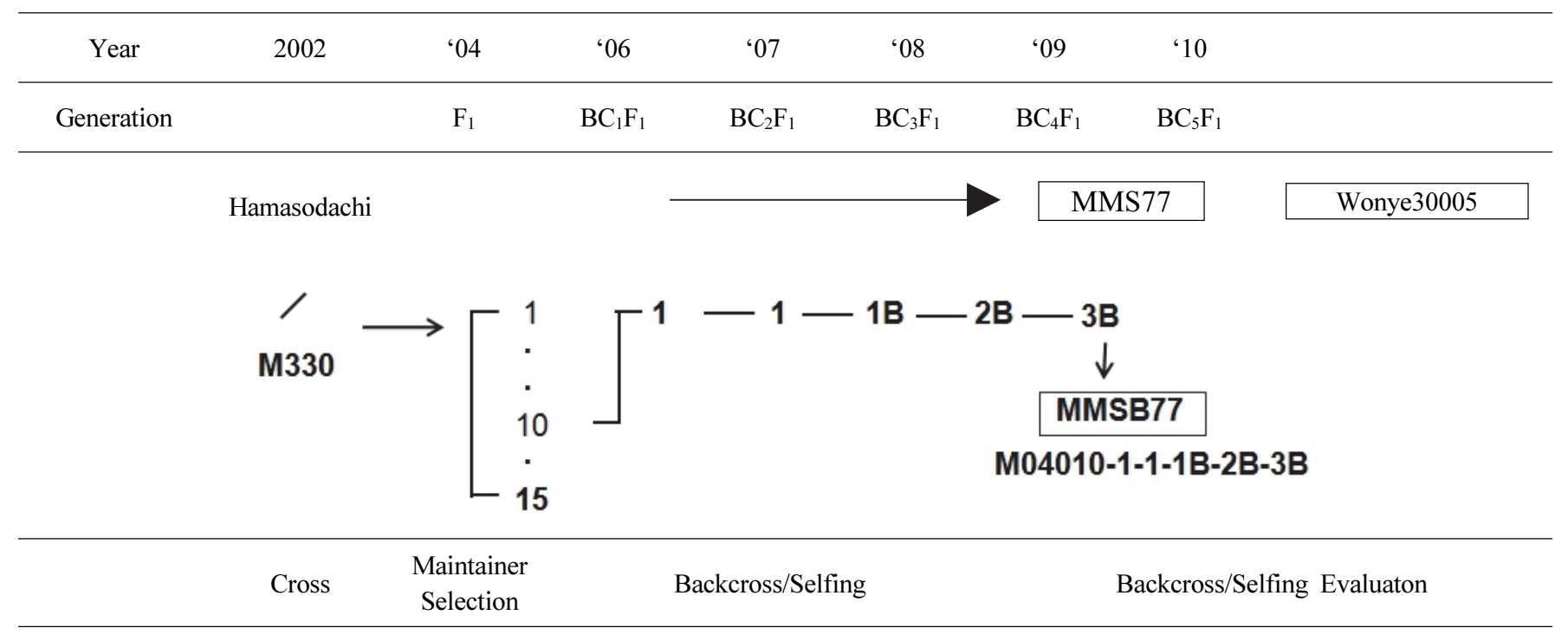

Fig. 1. Pedigree diagram of 'Wonye 30005'

분자마커들이 개발되어 웅성불임계통과 유지계통을 선발기간 이 크게 단축되었으나(Havey 1995, Sato 1998, Engelke et al. 2003, Kim et al. 2009b) 여교배를 통한 형질고정은 여전히 장기간의 육종기간을 필요로 하고 있다. 따라서 국립식량과학원 바이오에너지작물센터에서는 웅성불임계통을 육성하여 종묘회 사에 보급하여 $\mathrm{F}_{1}$ 품종 육성기간을 단축시키고자 2010년에 웅성 불임계통 ‘원예30001'을 육성(Kim et al. 2010)한 이래 현재까 지 6품종을 품종보호 출원하였다. 본 연구에서는 숙기가 빠르고 구형과 저장성이 좋아 조생계 $\mathrm{F}_{1}$ 종자 생산에 유리한 특성을 가진 '원예 3005 '를 개발한바 육성경위와 주요특성을 보고하고 자 한다.

\section{재료 및 방법}

'원예30005'는 조생계 도입품종인 '하마소다치'의 자식계통 에서 선발한 웅성불임개체와 자식계통인 'M330'를 교배하여 육성하였다. 채종모구 정식은 매년 11월 20일에 비가림 채종하 우스에 하였고 재식밀도는 $30 \times 40 \mathrm{~cm}$ 로 웅성불임계통과 유지계 통 채종모구를 각각 25 개씩 정식하였다. 모구가 개화하기 전에 격리망을 설치하여 연두금파리를 수분매개충으로 하여 교배하 였다. 채종모구 선발과 교배는 국립식량과학원 바이오에너지작 물센터 시험포장과 채종하우스에서 수행하였다. '원예 30005 '의 생육 및 수량특성 검정은 2009 2010년까지 2년에 걸쳐 수행하 였다. 생육특성검정은 매년 9월 20일에 파종하고 11 월 10일에
13 공 백색 유공필름으로 피복한 후 정식하였다. 시비량 및 시비 법은 양파 표준재배법에 준하였다. 채종용 모구는 상온에서 저장 하였으며 모구를 선발하여 11 월 20일에 채종하우스에 정식하였 다. 생육 및 수량특성과 개화기, 화경수 등 채종 관련 특성조사는 신품종심사를 위한 양파 특성조사요령(KSVS 2011)과 시험계 획서의 조사기준에 준하여 수행하였다. 특성검정 기간 중 노균병 저항성은 자연 감염된 개체수를 조사하였고 내한성은 월동 후 결주율을 조사하였으며 저장성은 모구 수확 후 상온저장 시 맹아율을 조사하여 분석하였다. 각 특성의 저항성 정도는 전체개 체수의 $10 \%$ 이하이면 저항성(R, resistance), $11 \sim 30 \%$ 이면 중도 저항성(MR, moderate resistance), $31 \%$ 이상일 경우 감수성 $(\mathrm{S}$, susceptible)으로 표기하였다.

\section{결과 및 고찰}

\section{육성경위}

웅성불임계통은 양파 $\mathrm{F}_{1}$ 종자생산에 필수적인 교배모본이다. ‘원예30005'는 2002년에 조생품종 ‘하마소다치' 집단에서 선발 한 웅성불임 개체와 조생계 자식계통 'M330'에서 선발한 화분친 을 교배하여 육성하였다. $\mathrm{F}_{1}$ 조합에서 유지계통을 확인하여 2010 년까지 5 세대에 걸쳐 여교배하여 형질을 고정하였다. 2006 2007년에는 단교배법으로 교배하였고 2008년부터 2010 년까지 집단 채종하였다(Fig. 1). 2009년에 BC4F1을 'MMS77' 로 명명하고 생육특성과 채종특성을 평가하였으며 육성과정은 


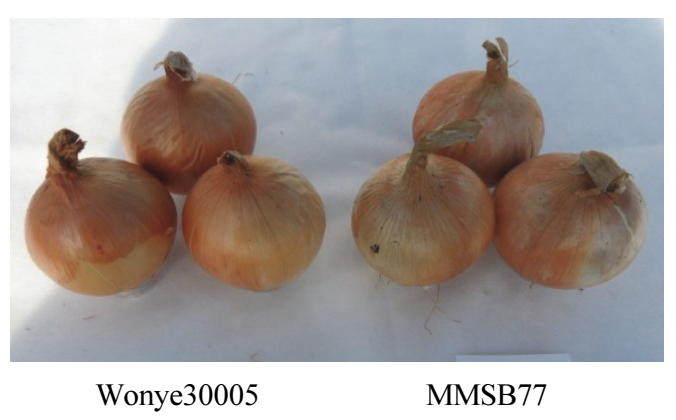

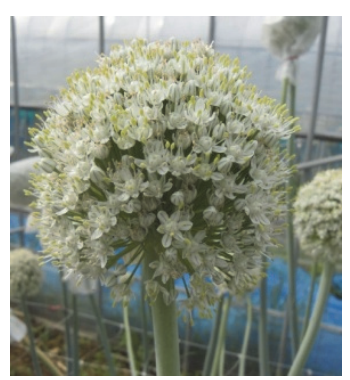

Wonye30005

(MMS77)

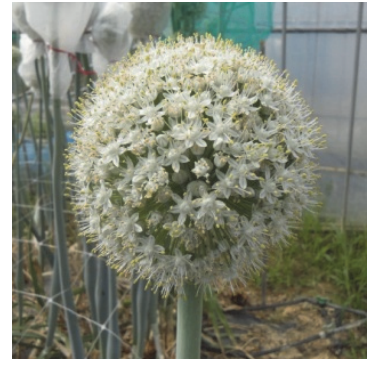

MMSB77

Fig. 2. Mother bulb plants and flowers of 'Wonye30005' and maintainer line (MMSB77).

Table 1. Inheritance plant characteristics of 'Wonye 30005 '

\begin{tabular}{cccccccccc}
\hline \multicolumn{1}{c}{ Cultivar } & & Plant type & Leaf colour & Bulb shape & Bulb skin colour & Lodging date & Fertility & pollen color \\
\hline $\begin{array}{c}\text { Wonye30005 } \\
\text { (MMS77) }\end{array}$ & O & Erect & Green & Circular & Brown & May 10 & Male sterile & green \\
MMSB77 & $0^{7}$ & Erect & Green & Circular & Brown & May 9 & Male fertile yellow \\
\hline
\end{tabular}

Table 2. Morphological characteristics of 'Wonye 30005 '

\begin{tabular}{|c|c|c|c|c|c|}
\hline Cultivar & & $\begin{array}{l}\text { Plant height } \\
(\mathrm{cm})\end{array}$ & $\begin{array}{l}\text { Leaf number } \\
\text { per plant }\end{array}$ & $\begin{array}{l}\text { Pseudostem diameter } \\
\qquad(\mathrm{mm})\end{array}$ & $\begin{array}{l}\text { Pseudostem length } \\
(\mathrm{cm})\end{array}$ \\
\hline $\begin{array}{l}\text { Wonye } 30005 \\
\text { (MMS77) }\end{array}$ & ㅇ & $61 \pm 4.3^{\mathrm{z}}$ & $7.2 \pm 0.8$ & $11.5 \pm 1.9$ & $16.0 \pm 1.1$ \\
\hline MMSB77 & $0^{x}$ & $58 \pm 6.8$ & $6.4 \pm 0.7$ & $10.4 \pm 1.3$ & $16.0 \pm 1.1$ \\
\hline
\end{tabular}

$\mathrm{Z}$ The values are given as mean \pm standard deviation $(\mathrm{n}=5)$

Fig. 1과 같다. 2010년 농작물 직무육성 신품종선정심의위원회 에서 양파 $\mathrm{F}_{1}$ 종자 생산용 중간모본으로 선정되었다. 2011년에 ‘원예30005'로 명명하여 품종보호 출원(2011-365)하여 2013년 에 품종보호등록(제4673호) 되었다.

\section{생육 및 수량특성}

‘원예 30005 '의 고유특성인 초형은 직립형, 구색은 황색, 도복 기는 5 월 10 일로 조생계통에 속하며 임성은 불임이며 약색은 녹색이다 (Table 1, Fig. 2). ‘원예30005'의 유지계통인 'MMSB77'은 '원예30005'와 고유특성에는 차이가 없었으나 임성은 가임이다. 생육특성 중 초장이 $61 \mathrm{~cm}$ 로 'MMSB77'의 $58 \mathrm{~cm}$ 보다 크고 주당엽수 7.2매, 엽초경 $11.5 \mathrm{~mm}$ 로 유지계통의 6.4 매, $10.4 \mathrm{~mm}$ 에 비해 생육이 좋다. 엽초장은 차이가 없었으며 구중은 $253 \mathrm{~g}$ 으로 'MMSB77'의 $190 \mathrm{~g}$ 보다 무거웠다(Table 2).
구고와 구경은 각각 $78.2 \mathrm{~mm}, 75.8 \mathrm{~mm}$ 로 구의 형태를 나타내는 구형지수는 97로 원형에 속하며 'MMSB77'은 96으로 비슷한 구형을 나타냈다. '원예30005'와 'MMSB77'의 수량은 각각 $6,274 \mathrm{~kg} / 10 \mathrm{a}, 4,712 \mathrm{~kg} / 10 \mathrm{a}$ 으로 '원예30005'와 'MMSB77'의 수량차이가 있었다(Table 3). 'MMSB77'이 '원예30005'에 비 해 생육과 수량이 낮은 것은 순도유지를 위한 자식의 결과로 여겨진다.

\section{노균병 저항성, 내한성, 저장성}

노균병(Peronospora destructor)은 세계적으로 널리 분포하는 곰팡이균으로 저온 다습한 조건에서 발생한다. 토양 전염하며 보통 이른 봄에 발생이 심하여 수량감소 및 저장성을 약화시킨다. 노균병균은 활물기생균으로 인공배양이 불가능하기 때문에 저 항성 검정을 위한 검정체계가 확립되지 않아 자연감염에 의한 
Table 3. Characteristics of mother bulb of '르 Wonye 30005 '

\begin{tabular}{|c|c|c|c|c|c|c|}
\hline Cultivar & & $\begin{array}{l}\text { Bulb height } \\
\text { (mm) }\end{array}$ & $\begin{array}{c}\text { Bulb }^{\mathrm{z}} \text { diameter } \\
(\mathrm{mm})\end{array}$ & Bulb index ${ }^{y}$ & $\begin{array}{c}\text { Bulb weight } \\
\text { (g) }\end{array}$ & Yield $^{\mathrm{x}}(\mathrm{kg} / 10 \mathrm{a})$ \\
\hline $\begin{array}{c}\text { Wonye } 30005 \\
\text { (MMS77) }\end{array}$ & 우 & $78.2 \pm$ & $75.8 \pm$ & 97 & $253 \pm 10.5$ & $6,274^{\mathrm{a}}$ \\
\hline MMSB77 & $0^{x}$ & $73.8 \pm 4.5$ & $71.0 \pm 3.4$ & 96 & $190 \pm 19.8$ & $4,712 b$ \\
\hline
\end{tabular}
\begin{tabular}{l}
\hline${ }^{\mathrm{x}}$ Different letters within columns indicate significant difference based on Duncan's multiple range test at $\mathrm{p}=0.05,{ }^{\mathrm{y}} \mathrm{Bulb}$ index $=$ \\
[Bulb height/Bulb diameter $] \times 100,{ }^{\mathrm{Z}}$ The values are given as mean \pm standard deviation $(\mathrm{n}=5)$
\end{tabular}

Table 4. Resistance of downy mildew, cold tolerance and storage ability of 'Wonye30005'

\begin{tabular}{ccccc}
\hline Cultivar & & Downy mildew & Cold tolerance & Storage ability \\
\hline $\begin{array}{c}\text { Wonye30005 } \\
\text { (MMS77) }\end{array}$ & $\circ$ & MR & $\mathrm{R}$ & $\mathrm{R}$ \\
MMSB77 & $0^{*}$ & MR & $\mathrm{R}$ & $\mathrm{R}$ \\
\hline
\end{tabular}

b MR; Moderate resistance, R; Resistance

Table 5. Flowering characteristics of mother bulb for seed harvesting of 'Wonye 30005'

\begin{tabular}{|c|c|c|c|c|c|c|}
\hline \multirow[b]{2}{*}{ Cultivar } & & \multirow[b]{2}{*}{ Flowering date } & \multicolumn{2}{|c|}{ Flower stalk } & \multirow[b]{2}{*}{$\begin{array}{l}\text { Umbel diameter } \\
\qquad(\mathrm{mm})\end{array}$} & \multirow[b]{2}{*}{ Fertility } \\
\hline & & & $\begin{array}{l}\text { Length } \\
(\mathrm{cm})\end{array}$ & $\begin{array}{c}\text { Number } \\
\text { /mother bulb }\end{array}$ & & \\
\hline $\begin{array}{l}\text { Wonye } 30005 \\
\text { (MMS77) }\end{array}$ & 우 & May 25 & 134 & 4 & 84 & Male sterile \\
\hline MMSB77 & $0^{x}$ & May 24 & 108 & 3 & 100 & Male fertile \\
\hline
\end{tabular}

감염주를 조사하여 분석하였다. 국내에서 재배되고 있는 품종 중에서는 노균병에 강한 품종이 없는 실정이나 ‘원예 30005 '와 'MMSB77'는 포장상태에서 노균병에 다소 저항성을 보였으며 $\mathrm{F}_{1}$ 품종육성에 유용한 특성으로 여겨진다. '원예30005'는 조생 계통이지만 양친 모두 내한성과 저장성이 높은 특성을 보였다 (Table 4).

\section{채종특성}

'원예30005'와 'MMSB77' 채종모구의 개화기는 각각 5 월 25일과 5월 24일로 개화기가 비슷하여 수분 수정에 유리한 특성 이 있다. 주당 화경수는 각각 4 개, 3 개이며 화경장은 $134 \mathrm{~cm}$, $108 \mathrm{~cm}$ 로 '원예3005'의 화경이 길고 화구크기는 '원예30005'가 $84 \mathrm{~mm}$, 'MMSB77'은 $100 \mathrm{~mm}$ 로 화경이 더 크다. '원예30005' 의 약색은 녹색이며 'MMSB77'은 황색이다(Table 5, Fig 2).

\section{재배상 유의점}

채종용 모구는 구가 크면 저장성이 낮아지고 저장비용이 많이 소요되므로 지나친 시비와 관수를 억제하여야 한다. 표준시비량 을 준수하고 조생계통은 중만생종에 비해 저장성이 떨어지므로 채종용 모구저장은 수확 후 충분히 건조시켜 통풍이 잘되는 실내에 저장해야 한다. 채종용 모구는 비가림비닐하우스에 정식 하고 밀식할 경우 화경이 도장하므로 충분한 정식밀도를 유지하 여야 한다. 화경 출현 전에 도복 방지망을 설치하여 화경의 도복 을 방지하고 개화전에 격리망을 설치하여 화분혼입을 방지한다. 개화기에는 화분 매개충을 충분히 방사하여 수분을 조장하고 통풍이 잘되도록 관리한다.

\section{적 요}

‘원예30005'는 조생품종인 '하마소다치'에서 웅성불임개체 를 선발하여 조생계 자식계통인 'M330'에서 선발한 화분친과 
교배하여 육성하였다. $100 \%$ 웅성불임성을 보인 $\mathrm{F}_{1}$ 집단을 선발 하여 형질고정을 위해 5회 여교잡하였다. 2009년에 BC4F1을 'MM77'로 유지계통을 'MMSB77'로 명명하고 2009년부터 2010년 까지 특성검정을 시행하였다. 초형은 직립, 구색은 황색 이며 도복기는 5 월 10 일로 조생계통이다. 초장은 $61 \mathrm{~cm}$, 주당 엽수는 7.2매이며 엽초경과 엽초장은 각각 $11.5 \mathrm{~mm}, 16 \mathrm{~cm}$ 이다. 구중은 $253 \mathrm{~g}$ 으로 중구형이며 구형은 구형지수가 97 인 원형이 다. 내한성이 강하고 저장성이 높은 특성을 가지고 있지만 노균병 에는 다소 저항성을 보인다. 채종모구의 개화기는 5 월 25 일, 화경수는 4 개, 화경장과 화구 폭은 각각 $134 \mathrm{~cm}, 84 \mathrm{~mm}$ 이며 약색이 녹색인 웅성불임계통이다.

\section{사 사}

본 논문은 농촌진흥청 연구사업(과제번호: PJ00870702201 $5)$ 의 지원에 의해 이루어진 것임.

\section{REFERENCES}

1. Berninger E. 1965. Contribution a I'etude de la sterilitie male de I'oignon (Allium cepa L.). Ann. Amelior Plant 15: 183-199.

2. Engelke T, Terefe D, Tatlioglu T. 2003. A PCR-based marker system monitoring CMS-(S), CMS-(T) and (N)-cytoplasm in the onion (Allium cepa L.). Theor. Appl. Genet. 107: 162-167.

3. Havey MJ. 1995. Identification of cytoplasm using the polymerase chain reaction to aid in the extraction of maintainer lines from open-pollinated populations of onion. Theor. Appl. Genet. 90: 263-268.

4. Havey MJ. 2000. Diversity among male-sterility-inducing and male-fertile cytoplasms of onion. Theor. Appl. Genet. 101: 778-782.

5. Jones HA, Clarke AE. 1943. Inheritance of male sterility in the onion and the production of hybrid seed. Proc. Amer. Soc. Hort. Sci. 43: 189-194.

6. Korea Seed \& Variety Service (KSVS). 2011. Test guideline for onion. pp. 3-15.

7. Kim CW, Lee ET, Choi IH, Jang YS, Suh SJ. 2010. Mid-late maturing male sterile line of onion (Allium cepa L.) "Wonye 30001". Korean J. Breed. 42(3): 294-297.

8. Kim S, Lee ET, Kim CW, Yoon MK. 2009a. Distribution of three cytoplasm types in onion (Allium cepa L.) cultivars bred in Korea and Japan. Kor. J. Sci. Technol. 27(2): 275-279.

9. Kim S. Lee E, Cho DY, Han T, Bang H, Patil BS, Ahn YK, Yoon MK. 2009b. Identification of a novel chimeric gene, orf725, and its use in development of a molecular marker for distinguishing among three cytoplasm types in onion (Allium cepa L.). Theor. Appl. Genet. 118: 433-441.

10. Sato Y. 1998. PCR amplification of CMS-specific mitochondrial nucleotide sequences to identify cytoplasmic genotypes of onion (Allium cepa L.). Theor. Appl. Genet. 96: 367-370.

11. Schweisguth B. 1973. Etude d'un nouveau type de sterlite male shez l'oignon Allium cepa L. Ann Amelior Plant 23 : 221-233. 